\title{
PROTECTIVE EFFECT OF CASSIA FISTULA EXTRACTS AGAINST ULTRAVIOLET C INJURY IN HUMAN CORNEAL EPITHELIAL CELLS
}

\author{
DEEKSHA K ${ }^{1,2}$, CYNTHIA ARUNACHALAM ${ }^{2 *}$ \\ ${ }^{1}$ Department of Ophthalmology, Yenepoya Medical College, Yenepoya (Deemed to be University), Mangalore - 575 018, Karnataka, India, \\ ${ }^{2}$ Yenepoya Research Centre, Yenepoya (Deemed to be University), Mangalore - 575 018, Karnataka, India. \\ Email: cynthiaarunachalam@yahoo.com
}

Received: 24 July 2018, Revised and Accepted: 04 September 2018

ABSTRACT

Objective: The objective of this study was to investigate the antioxidant activity of Indian laburnum (Cassia fistula L. [CF]) leaf extracts and their impact on ultraviolet C (UVC) radiation-induced damage on human corneal epithelial (HCE) cells.

Methods: The antioxidant activity and free radical scavenging ability of CF leaf extracts were determined by in vitro methods such as 1,1-diphenyl2-picrylhydrazyl radical scavenging capacity, Total antioxidant capacity (TAC), and reducing power. The total phenolic content (TPC), total flavonoid content (TFC), and preliminary phytochemical screening were done to ensure the pharmacological effects of the extracts. The UVC radiation at wavelength $254 \mathrm{~nm}$ was used to irradiate HCE cells and cell viability was assessed by methyl thiazolyl tetrazolium assay.

Results: Extracts at the concentration of $200 \mu \mathrm{g} / \mathrm{ml}$ did not affect the cell viability of HCE cells. Almost $50 \%$ cell death was observed after UVC irradiation at a dose of $200 \mathrm{~J} / \mathrm{m}^{2}$. Both extracts showed a protective effect by increasing the cell viability of irradiated cells up to $57.28 \%$ and $62.39 \%$. A dose-dependent increase in the TAC and reducing power of the extract was observed. The TPC in aqueous and ethanol extracts of CF leaves was 18.8 and $27.80 \mathrm{mg}$ gallic acid equivalent/g sample while TFC was 8.47 and $16.5 \mathrm{mg}$ quercetin equivalent per/gsample, respectively.

Conclusions: CF leaves are a potent source of bioactive compounds with good antioxidant potential. Exposure to UVC radiation cause harmful effects on HCE cells and the extracts have shown to have potent protective effects on UV light-induced oxidative stress in HCE cells.

Keywords: Corneal epithelium, Ultraviolet rays, Antioxidant, Cassia fistula

(C) 2019 The Authors. Published by Innovare Academic Sciences Pvt Ltd. This is an open access article under the CC BY license (http://creativecommons. org/licenses/by/4. 0/) DOI: http://dx.doi.org/10.22159/ajpcr.2019.v12i2.29562

\section{INTRODUCTION}

Photochemical damage to ocular tissues is caused by solar radiation and other ultraviolet (UV) sources. Since ocular tissues do not develop tolerance to UV exposure, excessive exposure of UV radiation to the ocular surface is damaging to the eye. The corneal epithelium is the external layer of the eye which is directly exposed to the UV radiation of the sun. Wavelengths from 400 to $100 \mathrm{~nm}$ are within the UV spectrum which is further categorized as UVA $400-315 \mathrm{~nm}$, UVB 315-280 nm, UVC 280-200 nm, and UV vacuum 200-100 nm [1]. The shorter and more toxic wavelengths of UVC and UV vacuum are blocked from reaching the earth by ozone in the stratosphere. However, the eye is susceptible to UVC radiation during occupational exposures by artificial sources such as welding arcs, tanning lamps, therapeutic high-intensity UV for skin conditions or seasonal affective disorder, germicidal UV lamps in hospital and research purpose, and also from the sun through reflection from snow and water. Cornea absorbs $100 \%$ of UVC radiation; hence, cornea is more susceptible to UVC-induced oxidative damages than the other parts of the eye such as lens and retina [2].

Antioxidants are free radical scavengers which inhibit protein denaturation and lipid peroxidation, by protecting the human body from several diseases caused due to the triggering of reactive oxygen species (ROS). Oxidative stress occurs due to the imbalance between the generation of ROS and cellular antioxidant enzymes present in the body [3]. Medicinal plants are known to possess a number of antioxidants. These natural antioxidants are shown to reduce oxidative damage and the development of major diseases. Various studies have been carried out on numerous plants and are a potential source of antioxidants.
Cassia fistula L. is used in phytochemical and pharmacological research due to their excellent medicinal values and this potent herb is used as an alternative medicine for centuries. The plant is also used for adenopathy, burning sensations, leprosy, skin diseases, syphilis, and tubercular glands. It has mildly laxative, constringent, and anthelmintics property [4] and used as a treatment for burns, convulsions, constipation, cancer, hematuria, delirium, epilepsy, diarrhea, hematuria, pimples, and glandular tumors. The leaves have been used since ancient times for treating malaria, ulcers, rheumatism, fever, and constipation, skin disease such as leprosy, abdominal pain, and heart disease [5]. Yunani uses the leaves for inflammation, antipyretic, abortifacient, demulcent, purgative, chest complaints, eye ailments, flu, and rheumatism [6]. In Ayurvedic classics, this plant is mainly used as laxative during fever (Mrudurechaka) and many conditions such as skin diseases (Kushta), rheumatic diseases (Amavaata), cervical lymphadenitis (Gandamala), cardiac diseases (Hrudroga), worm infestations (Krimi), abdominal pain (Shoola), abdominal disorders (Udararoga), polyuria (Prameha), dysuria (Mutrakrichra), and bloating of abdomen (Gulma). It is also said to be the best for the elimination of different dosha of the gastrointestinal tract [7]. Acharya Sushruta has indicated the use of Aragvada in netrapaka in the form of raskriya [8]

Since it is important to prevent the UV-induced oxidative damage, we thought that medicinal plants may protect the cornea from UVinduced oxidative stress, and also, CF is known to possess various pharmacological activities. We thought that medicinal plants may protect the cornea from UV-induced oxidative stress, and also, CF is known to possess various pharmacological activities. Hence, we chose this plant as a powerful candidate for our study. Till date, the effect of 
CF extracts on UV-induced damages in human corneal epithelial (HCE) cells is not studied.

Therefore, in the present study, we aimed to investigate the antioxidant activities of the aqueous and ethanol extracts of $\mathrm{CF}$ leaves and check the protective effect of these extracts on UVC-induced damage in HCE cells.

\section{METHODS}

\section{Plant material}

The leaves of CF $L$. were collected from Yenepoya (Deemed to be University) garden, Derlakatte, Mangalore, and were identified by the botanist.

\section{Extracts preparation}

The air-dried plant powder was subjected to maceration using solvents such as aqueous and ethanol extracts for $24 \mathrm{~h}$ in a shaker incubator. After $24 \mathrm{~h}$, the extract was centrifuged and the supernatant was filtered using Whatman filter paper, and then, the extracts were concentrated using a Speedvac Concentrator and the dry residue was kept in a refrigerator at $4^{\circ} \mathrm{C}$ for further analysis [5].

\section{Phytochemical screening}

The condensed extracts was used for preliminary screening of phytochemicals such as alkaloids (Wagner and Mayer's tests), flavonoids (alkaline reagent test), carbohydrates (Molisch's test, Fehling's test, and Barfoed's test), glycosides (Legal's test), saponins (foam test), protein's (Biuret test), amino acids (Ninhydrin test), sterols (Liebermann-Burchard test), phenolic compounds, and tannins (gelatin test, ferric chloride test, and lead acetate test). All the tests were carried out using standard protocol [9-12].

\section{Cell line and culture}

HCE cells were cultured in Dulbecco's modified Eagle's medium/Hams F12 (1:1) supplemented with 10\% heat-inactivated fetal bovine serum and antibiotic-antimycotic solution and maintained at $37^{\circ} \mathrm{C}$ and $5 \% \mathrm{CO}_{2}$ humidity.

\section{Cytotoxicity assay}

HCE cells were treated with different concentrations of extracts and incubated for $48 \mathrm{~h}$ and the cell viability was assessed by standard spectrophotometric methyl thiazolyl tetrazolium (MTT) assay. Briefly, cells were plated at a density of 5000 cells/well in 96-well microplates. After incubation for $24 \mathrm{~h}$, the selected plant extracts were added to the culture medium at different concentrations $(12.5-200 \mu \mathrm{g} / \mathrm{ml})$ and incubated for $48 \mathrm{~h}$. Then, MTT solution was added, followed by the addition of dimethyl sulfoxide after $4 \mathrm{~h}$ to solubilize the formazan crystals. The absorbance was taken at $570 \mathrm{~nm}$ using multimode microplate reader (FluoSTAR Omega, BMG Labtech, Ortenberg, Germany). The cell viability was expressed as the percentage of the control.

\section{UVC irradiation}

Cells were irradiated with UVC radiation $\left(254 \mathrm{~nm}\right.$ ) at a dose of $200 \mathrm{~J} / \mathrm{m}^{2}$ using UVP-2000 UV crosslinker, and after $1 \mathrm{~h}$, cells were incubated with aqueous and ethanol extracts of CF leaves $(12.5 \mu \mathrm{g} / \mathrm{ml})$ followed by MTT assay.

\section{ESTIMATION OF ANTIOXIDANT ACTIVITY}

Total antioxidant capacity (TAC) assay by phosphomolybdate method The total antioxidant capacity of the $\mathrm{CF}$ leaf extracts was evaluated by the phosphomolybdenum method [13]. Ascorbic acid (AA) was used as a standard antioxidant. Different concentration of plant extracts ranging from 50 to $600 \mu \mathrm{g} / \mathrm{ml}$ was taken for the experiment. The experiment was performed in triplicates $(n=3)$. The antioxidant activity of the extracts was expressed in terms of AA equivalents AAE.

\section{1,1-diphenyl-2-picrylhydrazyl (DPPH) free radical scavenging activity}

The antioxidant activities of plant extracts and the standard were assessed on the basis of the free radical scavenging ability of DPPH by modified method [14]. Plant extract at concentrations $(50-600 \mu \mathrm{g} / \mathrm{ml})$ was taken for the experiments. The L-AA $(100 \mu \mathrm{g} / \mathrm{ml})$ was used as standard. The experiment was performed in triplicates $(n=3)$ and the percentage radical scavenging activity was calculated using the formula:

\% Radical scavenging ability $=($ Ac-AE $) \times 100 / A c$

Where,

Ac is the absorbance of control (DPPH), AE is the absorbance of test. The decrease in the absorbance of DPPH solution indicates an increase in the DPPH radical scavenging activity.

\section{Determination of reducing power}

Ferric reducing antioxidant power (FRAP)

Reducing ability of the plant extracts was investigated based on the procedure developed by Oyaizu [15]. Different concentrations of the plant extracts $(250,500$, and $1000 \mu \mathrm{g} / \mathrm{ml})$ were used for the experiments. The experiments were performed in triplicate $(n=3)$. L-AA was used as a standard

\section{Quantitative phytochemical screening}

Total phenolic content (TPC)

The TPC of the plant extract was investigated according to the standard protocol [16]. Gallic acid was used as a standard. The samples were taken in triplicates $(n=3)$. The TPC was expressed as gallic acid equivalents (mg GAE/g extract).

\section{Total flavonoid content (TFC)}

TFC of the plant extracts was determined according to standard protocol [17]. Quercetin was used as a standard. All samples were taken in triplicate $(\mathrm{n}=3)$. The TFC was expressed as quercetin equivalents (mg QE/g extract).

\section{Statistical analysis}

Data are represented as mean \pm standard deviation from three experiments. Data were analyzed using one-way analysis of variance with Dennett post hoc test. Differences of $\mathrm{p} \leq 0.01$ were considered statistically significant.

\section{RESULTS}

\section{Effect of CF extracts on HCE cells}

The cell viability analysis of HCE cells was performed by MTT assay after $48 \mathrm{~h}$ incubation in aqueous and ethanol extracts of CF leaves at different concentrations $(12.5-200 \mu \mathrm{g} / \mathrm{ml})$. The cell proliferation was expressed as a percentage of control. Both aqueous and ethanol extract did not affect the viability and proliferative activity of the cells even at concentration of $200 \mu \mathrm{g} / \mathrm{ml}$ (Fig. 1).

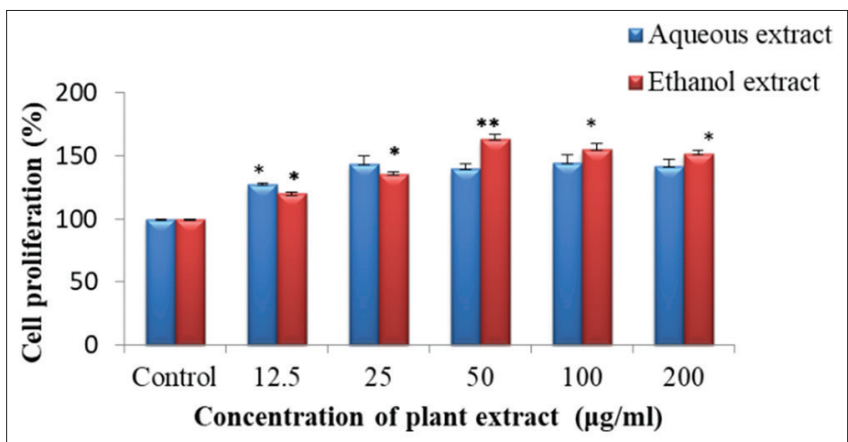

Fig. 1: Effect of aqueous and ethanol extracts of CF on human corneal epithelial cells. Cells were treated with different concentrations $(12.5-200 \mu \mathrm{g} / \mathrm{ml})$ of extracts and incubated for $48 \mathrm{~h}$ and the cell proliferation was determined by methyl thiazolyl tetrazolium assay. Data are represented as mean \pm standard deviation ( $n=3), p<0.01$ is considered statistically significant. CF: Cassia fistula 
Effect of CF extracts against UVC-induced injury in HCE cells

To investigate the protective effects of CF leaf extracts, the HCE cells were irradiated with UVC radiation $(254 \mathrm{~nm})$ at $200 \mathrm{~J} / \mathrm{m}^{2}$ using UVP$2000 \mathrm{UV}$ crosslinker, and after $1 \mathrm{~h}$, cells were incubated with aqueous and ethanol extracts at a concentration of $12.5 \mu \mathrm{g} / \mathrm{ml}$ followed by MTT assay. The results showed that UVC irradiation on HCE cells reduced the cell viability and caused cell death by $47 \%$. The cell death decreased after they were treated with $\mathrm{CF}$ aqueous and ethanol extracts. Both aqueous and ethanol extract showed high protective effect about $57.28 \%$ and $62.39 \%$ cell viability, respectively (Fig. 2).

\section{Phytochemical screening of extracts}

The aqueous and ethanol extracts of $\mathrm{CF}$ leaves were screened for phytochemical constituents. The aqueous extracts showed the presence of alkaloids, carbohydrates, protein, amino acids, flavonoids, phenolic compounds, and tannins. The ethanol extracts showed the presence of alkaloids, protein, amino acids, flavonoids, phenolic compounds, and tannins. These results confirmed that the extracts had a significant amount of bioactive compounds. The results are summarized in Table 1.

\section{Total antioxidant activity}

The total antioxidant capacity of aqueous and ethanol extracts of $\mathrm{CF}$ leaves was calculated using the standard curve of AA ( $y=0.012 x-0.971$; $\mathrm{R} 2=0.991$ ) and expressed as an AAE/g of extract. Both aqueous and ethanol extracts exhibited a dose-dependent increase in antioxidant activity shown in Fig. 3. Aqueous extract at concentrations of 50 and $600 \mu \mathrm{g} / \mathrm{ml}$ showed the antioxidant activity of 51.18 and $86.22 \mu \mathrm{M} \mathrm{AAE}$, respectively. Ethanol extract at concentrations of 50 and $600 \mu \mathrm{g} / \mathrm{ml}$ showed the antioxidant activity of 65.86 and $88.11 \mu \mathrm{M} \mathrm{AAE}$, respectively.

\section{DPPH radical scavenging activity}

Aqueous and ethanol extracts of $\mathrm{CF}$ leaves exhibited a significant DPPH scavenging activity as shown in Fig. 4. Aqueous extract exhibited $10.25 \%, 21.31 \%, 25.42 \%, 31.11 \%$, and $33.24 \%$ of scavenging activity at $50,100,200,400$, and $600 \mu \mathrm{g} / \mathrm{ml}$ concentrations, respectively, whereas ethanol extract exhibited 32.85\%, 60.94\%, 70.46\%, 71.24\%, and $54.43 \%$ with the same concentrations. The standard AA showed $94.73 \%, 94.92 \%, 94.81 \%, 86.17 \%$, and $82.58 \%$ of the activity with the same concentrations. Ethanolic extracts showed the highest activity when compared to aqueous extracts. Percentage of scavenging activity or percentage inhibition was calculated by the linear regression method.

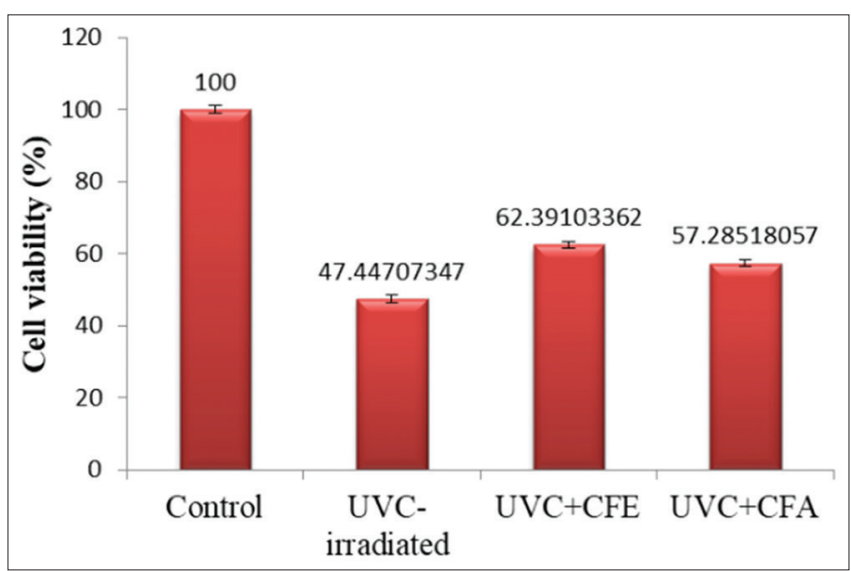

Fig. 2: Effect of aqueous and ethanol extracts of CF on UVC irradiated human corneal epithelial cells. Cells were irradiated with UVC radiation at a dose of $200 \mathrm{~J} / \mathrm{m}^{2}$, and after $1 \mathrm{~h}$, cells were incubated with aqueous and ethanol extracts of $\mathrm{CF}$ leaves $(12.5 \mu \mathrm{g} / \mathrm{ml})$ followed by methyl thiazolyl tetrazolium assay. Data are represented as mean \pm standard deviation $(n=3)$. CFA: Aqueous extracts of Cassia fistula leaves; CFE: Ethanol extract of Cassia fistula leaves; UVC: Ultraviolet C, CF: Cassia fistula
Reducing power ability

The reducing power ability of aqueous and ethanol extracts of the leaves of CF was tested as shown in Fig. 5. Among the two extracts, the highest percentage of reducing power ability was seen in ethanol extract than the aqueous extract when compared to standard AA. There was a dosedependent increase in the reducing power ability in both aqueous and ethanol extracts of CF leaves.

Total phenolic and flavonoid content of the CF leaves

The TPC in aqueous and ethanol extract of CF leaves was found to be 18.8 and $27.80 \mathrm{mg} \mathrm{GAE} / \mathrm{g}$ extract, respectively. The TFC in aqueous and ethanol extracts of CF leaves was found to be 8.47 and $16.5 \mathrm{mg} \mathrm{QE} / \mathrm{g}$ extract, respectively. The results are shown in Table 2.

Table 1: Screening of the phytochemicals of CF leaf extracts

\begin{tabular}{|c|c|c|}
\hline \multirow[t]{2}{*}{ Tests } & \multicolumn{2}{|c|}{ CF extracts } \\
\hline & Aqueous & Ethanol \\
\hline \multicolumn{3}{|l|}{ Alkaloids } \\
\hline Mayer's test & + & + \\
\hline Wagner's test & - & - \\
\hline \multicolumn{3}{|l|}{ Carbohydrates and glycosides } \\
\hline Molisch's test & - & - \\
\hline Fehling's test & + & - \\
\hline Legal's test for glycosides & - & - \\
\hline \multicolumn{3}{|l|}{ Saponins } \\
\hline Foam test & - & - \\
\hline \multicolumn{3}{|l|}{ Protein and amino acids } \\
\hline Biuret test & + & + \\
\hline Ninhydrin test & + & + \\
\hline \multicolumn{3}{|l|}{ Phytosterols } \\
\hline Liebermann-Burchard's test & - & - \\
\hline \multicolumn{3}{|l|}{ Phenolics and tannins } \\
\hline $\mathrm{FeCl}_{2}$ test & + & - \\
\hline Gelatin test & - & - \\
\hline Lead acetate test & + & + \\
\hline \multicolumn{3}{|l|}{ Flavonoids } \\
\hline Alkaline reagent test & + & + \\
\hline
\end{tabular}

$(+)$ indicates the presence of the phytocompound and (-) indicates the absence of phytocompound. CF: Cassia fistula

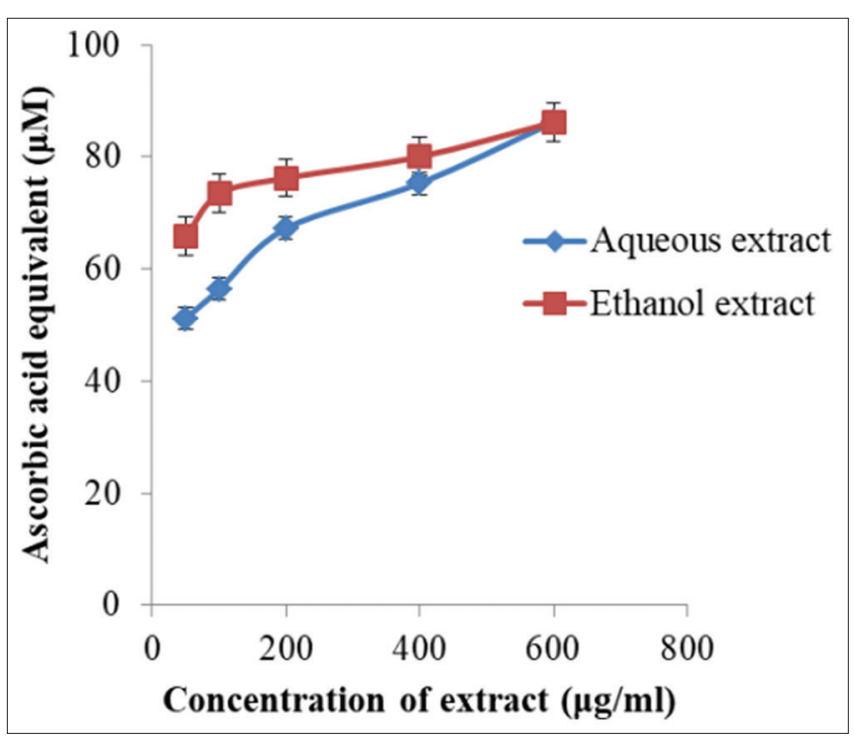

Fig. 3: Total antioxidant activity of aqueous and ethanol extracts of CF leaves. Different concentrations $(50-600 \mu \mathrm{g} / \mathrm{ml})$ of extracts were taken and evaluated for their TAC. Values are expressed as the mean \pm standard deviation $(n=3)$. Ascorbic acid (AA) was used as a standard. The antioxidant activity is expressed as equivalents of ascorbic acid 


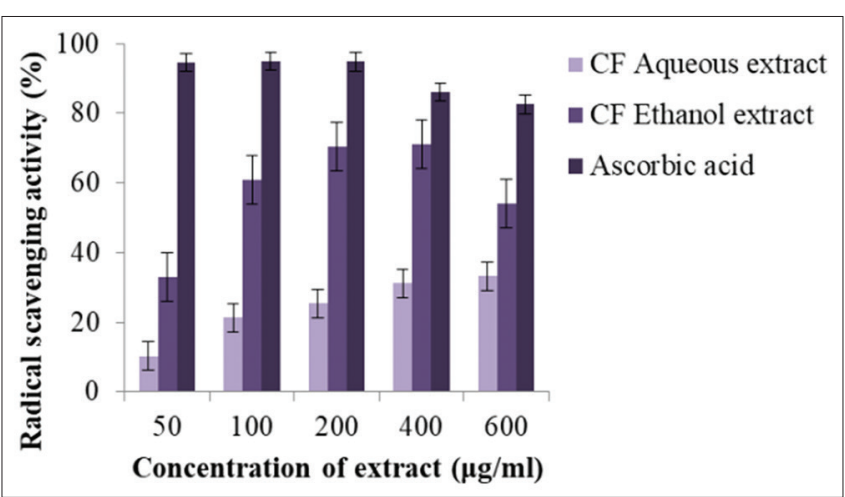

Fig. 4: 1,1-diphenyl-2-picrylhydrazyl (DPPH) radical scavenging activity of aqueous and ethanol extracts of CF leaves. Different concentrations $(50-600 \mu \mathrm{g} / \mathrm{ml})$ of extracts were taken and evaluated for their DPPH scavenging ability. Values are expressed as the mean \pm standard deviation $(n=3)$. Ascorbic acid at concentrations $(50-600 \mu \mathrm{g} / \mathrm{ml})$ was used as a standard. $p<0.01$ is considered statistically significant. CF: Cassia fistula

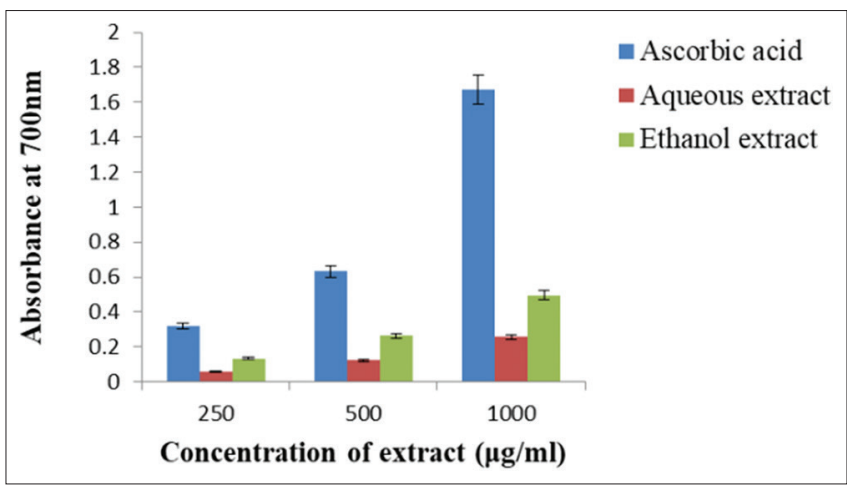

Fig. 5: Reducing power ability of aqueous and ethanol extracts of CF leaves. Different concentrations $(250,500$, and $1000 \mu \mathrm{g} / \mathrm{ml})$ of extracts were taken and evaluated by ferric reducing antioxidant power method. Values are expressed as the mean \pm standard deviation $(n=3)$. Ascorbic acid was used as a standard. $p<0.01$ is considered statistically significant. CF: Cassia fistula

\section{DISCUSSION}

Medicinal plants are known to possess various bioactive compounds with potential health benefits and medicinal properties. Since the plant compounds also contain toxic compounds, it is necessary to standardize the dose and check the cytotoxic effect on the cells. One of the ways to check the cytotoxicity of the extracts is by the in vitro cell culture method [18]. This study is done so that CF extracts can be used in the formulation of eye drops in future.

In the current study, the toxicity and antiproliferative activity of the aqueous and ethanol extracts of CF leaves was tested on HCE cells. The extracts even at high concentrations $(12.5-200 \mu \mathrm{g} / \mathrm{ml})$ did not show any cytotoxic effect on the cells. Furthermore, it did not interfere with the proliferative activity of the HCE cells. Since this plant extracts did not show any cytotoxic effect even at high concentrations on HCE cells, this extract proves to be less harmful to be used as a therapeutic agent for eye-related disorders and prophylaxis. Medicinal plant extracts with reduced cytotoxicity are needed to discover a potential drug.

Plants are known to possess potent antioxidant and free radical scavenging activities. The amount of phenolic compound directly correlates to the antioxidant activity of the plant extracts [19]. The scavenging ability is due to the presence of the hydroxyl group of the phenolic compounds. In the present study, the antioxidant activity of
Table 2: Total phenolic and flavonoid content of aqueous and ethanol extracts of $\mathrm{CF}$ leaves

\begin{tabular}{lll}
\hline \multirow{2}{*}{ Test } & \multicolumn{1}{c}{ CF leaves } \\
\cline { 2 - 3 } & Aqueous extract & Ethanol extract \\
\hline TPC (mg GAE/g extract)* & $18.8+0.019$ & $27.80 \pm 0.003$ \\
TFC (mg QE/g extract)* & $8.47 \pm 0.142$ & $16.5 \pm 0.003$ \\
\hline
\end{tabular}

TPC: Total phenolic content, TFC: Total flavonoid content, GAE: Gallic acid equivalent, CF: Cassia fistula, QE: Quercetin equivalents

the extracts was checked by TAC assay, DPPH assay, and FRAP assay. The TPC and TFC were also quantified.

The in vitro antioxidant activity of aqueous and ethanol extracts of CF leaves was tested and is discussed below. The DPPH scavenging ability of the extracts was evaluated against standard AA and it was found that ethanol extract at a concentration of $400 \mu \mathrm{g} / \mathrm{ml}$ showed the maximum DPPH scavenging activity of $71.24 \%$ than the aqueous extract which was similar to that of standard AA. The DPPH reduction is directly proportional to the antioxidant activity of the extract and due to the stabilization of the free radicals by the proton-donating ability of the extracts [20]. The proton radical scavenging action is an important mechanism for measuring antioxidant activity. This assay determines the scavenging of stable radical species DPPH by antioxidants compounds present in the extracts. The results indicate greater DPPH scavenging activity of ethanolic extracts as compared to the aqueous extracts which are probably due to the presence of high phenolic compounds. Our study clearly shows that the ethanolic extract of $\mathrm{CF}$ leaves exhibits high phenolic compounds which significantly correlate to the DPPH radical scavenging activity of the extracts $(\mathrm{p}<0.01)$. The findings of the study suggest that the extracts of CF leaf contain numerous bioactive phytocompounds which are capable of donating hydrogen to a free radical. The presence of alkaloids, carbohydrates, protein, amino acids, flavonoids, phenolic compounds, and tannins in the extracts is closely associated with medicinal properties such as the anti-inflammatory, antidiabetic, and analgesic activity of CF leaves [21].

The total antioxidant capacity of ethanol extract was found to be higher than the aqueous extract. There was a concentration-dependent increase in the total antioxidant activity in both ethanol and aqueous extract of CF leaves. The total antioxidant activity of the CF extracts corresponds to the capability to counteract ROS, resist the oxidative damage, and combat diseases caused due to oxidative stress [20].

The reducing power assay is done to evaluate the extracts ability to donate an electron [22]. The ethanol and aqueous extract of $\mathrm{CF}$ leaves showed good activity in reducing $\mathrm{Fe}^{+3}$ to ferrous ion. The extracts reveal their antioxidant activities by donating a hydrogen atom through breakage of the free radical chain and they convert the radicals into stable and non-toxic products. The reducing power sequence of the samples is as follows: AA>ethanol extract>aqueous extract. The reducing power of $\mathrm{CF}$ ethanol extracts was higher than the aqueous extract of CF leaves. Dose-dependent increase in the reducing power ability was observed in both ethanol and aqueous extracts. The reducing power assay is mostly used to evaluate the antioxidant ability to donate an electron which is an important mechanism of phenolic antioxidant action [23]. Previous studies have shown that there is a direct correlation between antioxidant activities and reducing the power of plant extracts $[24,25]$.

Plant phenol compounds possess potent antioxidant, antimicrobial, and anti-inflammatory activity [26-28]. The TFC in aqueous and ethanol extract was 8.47 and $16.5 \mathrm{mg} \mathrm{QE} / \mathrm{g}$ sample, respectively. High flavonoid content in ethanol extract contributes to the antioxidant, antimicrobial, and anti-inflammatory properties in various studies $[29,30]$.

UV rays act as a significant oxidative stimulus for the human eye, leading to the development of several eye disorders such as cataracts, 
photokeratitis, several retinopathies, as well as neoplasms. UV-induced pathologic changes in the eye are due to the generation of ROS, leading to protein, lipid, and DNA damage following epithelial cell viability loss [31]. In our study, we checked the efficacy of the $\mathrm{CF}$ leaf extracts in protecting HCE cells from UVC-induced injury by MTT assay. When the HCE cells were irradiated with UVC at $200 \mathrm{~J} / \mathrm{m}^{2}$, almost $50 \%$ cell death was observed which was found to be decreased after extract treatment. CF ethanol extracts at a concentration of $12.5 \mu \mathrm{g} / \mathrm{ml}$ exhibited a protective effect by increasing the cell viability up to $62.39 \%$. These results indicate that the ocular surface could be damaged by the exposure to UVC radiation $(254 \mathrm{~nm})$, and the application of medicinal plant extracts will be effective in decreasing the damage by their antioxidant activity. Among the two extracts evaluated, the ethanol extract proved to have high antioxidant activity and reducing power which is due to the presence of phenolic and flavonoid content which might be related to the reduction of ROS and an increase in the antioxidant enzymes. Previous studies have shown that the use of natural antioxidants has been helpful in reducing the oxidative stress in various parts of the eye. Antioxidants such as omega- 3 fatty acids and green tea polyphenols are known to have anti-inflammatory and antioxidant effects on HCE cells, the topical or systemic application of these antioxidants is known to decrease inflammatory markers in the tear film, ocular surface, and lacrimal gland of dry eye [32,33]. A mixture of ethanol extracts of four selected plants protected HCE cells from oxidative stress induced by light-emitting diode irradiation of shorter wavelengths through their antioxidant enzymatic defense system [34]. Abid et al. have reported that the CF extracts showed remarkable antioxidant and protective activity against induced oxidative stress in erythrocytes [35]. Methanolic and ethyl acetate extract of CF leaves are also known for its antihyperlipidemic and antiatherosclerotic activity as reported by Reddy et al. [36].

Taken together our results suggest that the CF leaves have good antioxidant and reducing power, and non-cytotoxic, and also, they are capable of protecting the HCE cells from UVC damage. Hence, they might also be effective in the treatment of oxidative stress-induced ocular surface diseases such as pterygium and dry eye diseases where the failure of antioxidant defense plays a pivotal role.

\section{CONCLUSIONS}

CF leaf extracts at low concentrations showed no toxicity to human corneal cells and protected the cells from UVC damage which might be due to their antioxidant potential. This in vitro study shows that the $\mathrm{CF}$ leaf has the therapeutic potential in the treatment of ocular surface inflammatory diseases. The present study was carried out only on aqueous and ethanol extracts of $\mathrm{CF}$ leaves. Additional studies can be done with other extracts with fractionates to evaluate the components in the plant extract. The study needs further validation by checking the level of antioxidant enzymes, ROS production at the cellular and molecular level. This validation will help further in elucidating the pathogenesis and treatment of oxidative stress-induced ocular surface diseases.

\section{ACKNOWLEDGMENTS}

The authors would like to acknowledge the financial support rendered by Yenepoya (Deemed to be University). The authors acknowledge Ms. Megha Nair for her help in statistical analysis.

\section{AUTHORS' CONTRIBUTIONS}

Deeksha K conceived, designed and performed the experiments, and analyzed the data. Dr. Cynthia Arunachalam provided the nurturing environment and intellectual insights. Both were involved in writing the paper.

\section{CONFLICTS OF INTEREST}

All authors have none to declare.

\section{REFERENCES}

1. Zigman S. Ocular light damage. Photochem Photobiol 1993;57:1060-8.

2. Tenkate TD. Occupational exposure to ultraviolet radiation: A health risk assessment. Rev Environ Health 1999;14:187-209.

3. Halliwell B, Gutteridge JM. Free radicals, other reactive species, and disease. Free Radic Biol Med 1999;3:617-783.

4. Bahorun T, Neergheen VS, Aruoma OI. Phytochemical constituents of Cassia fistula. Afr J Biotechnol 2005;4:1530-40.

5. Siddhuraju P, Mohan PS, Becker K. Studies on the antioxidant activity of Indian Laburnum (Cassia fistula L.): A preliminary assessment of crude extracts from stem bark, leaves, flowers, and fruit pulp. Food Chem 2002;79:61-7.

6. Raji P, Abila MG, Renugadevi K, Samrot AV. Phytochemical screening and bioactivity studies of Cassia fistula leaves. Int J Chem Tech Res 2014; 6:5096-100

7. Sangu PK, Sharma BK, Rajashekharan R, Prasad GP, Ala N. Medicinal properties of Aragvadha (Cassia fistula Linn.). Int J Ayurveda Res 2011; 1:129-33.

8. Kapoor LD. Handbook of Ayurvedic Medicinal Plant. Routledge: Herbal Reference Library; 2017.

9. Parekh J, Chanda S.V. In vitro antimicrobial activity and phytochemical analysis of some Indian medicinal plants. Turk J Biol 2007;31:53-8.

10. Kumar GS, Jayaveera KN, Kumar CK, Sanjay UP, Swamy BM, Kumar DV. Antimicrobial effects of Indian medicinal plants against acne-inducing bacteria. Trop J Pharm Res 2007;6:717-23.

11. Chanda SV, Parekh J, Karathia N. Evaluation of antibacterial activity and phytochemical analysis of Bauhinia variegate L. bark. Afr J Biomed Res 2006;9:53-6.

12. Sakat S, Juvekar AR, Gambhire MN. In vitro antioxidant and antiinflammatory activity of methanol extract of Oxalis corniculata Linn. Int J Pharm Pharm Sci 2010;2:146-55.

13. Prieto P, Pineda M, Aguilar M. Spectrophotometric quantitation of antioxidant capacity through the formation of a phosphomolybdenum complex: Specific application to the determination of Vitamin E. Anal Biochem 1999;269:337-41

14. Rajan S, Gokila M, Jency P, Brindha P, Sujatha RK. Antioxidant and phytochemical properties of Aegle marmelos fruit pulp. Int J Curr Pharm Res 2011:3:65-70.

15. Oyaizu M. Studies on products of browning reaction: Antioxidant activities of products of browning reaction prepared from glucosamine. Jpn J Nutr 1986;44:307-15

16. Kumar G, Karthik L, Rao KV. Antibacterial activity of aqueous extract of Calotropisgigantea leaves-an in vitro study. Int JPharm Sci Rev Res 2010; 4:141-4.

17. Kumaran A, Karakumaran J. In vitro antioxidant activities of methanol extracts of five Phyllanthus species from India. LWT - Food Sci Technol 2007;40:344-52

18. Piersma AH. Validation of alternative methods for developmental toxicity testing. Toxicol Lett 2004;149:147-53.

19. Ahmed D, Khan MM, Saeed R. Comparative analysis of phenolics, flavonoids, and antioxidant and antibacterial potential of methanolic, hexanic and aqueous extracts from Adiantum caudatum leaves. Antioxidants 2015;4:394-409.

20. Irshad M, Zafaryab M, Singh M, Rizvi M. Comparative analysis of the antioxidant activity of Cassia fistula extracts. Int J Med Chem 2012; 2012:157125

21. Kulkarni A, Govindappa M, Chandrappa CP, Ramachandra YL, Koka PS. Phytochemical analysis of Cassia fistula and it's in vitro antimicrobial, antioxidant and anti-inflammatory activities. Adv Med Plant Res 2015;3:8-17.

22. Yıldırım A, Mavi A, Oktay M, Kara AA, Algur ÖF, Bilaloğlu V. Comparison of antioxidant and antimicrobial activities of Tilia (Tilia argentea Desf ex DC), sage (Salvia triloba L.), and Black tea (Camellia sinensis) extracts. J Agric Food Chem 2000;48:5030-4.

23. Mohamed H, Ons M, Yosra ET, Rayda S, Neji G, Moncef N. Chemical composition and antioxidant and radical scavenging activities of Periploca laevigata root bark extracts. J Sci Food Agric 2009; 89:897-905.

24. Koleva II, Van Beek TA, Linssen JP, Groot AD, Evstatieva LN. Screening of plant extracts for antioxidant activity: A comparative study on three testing methods. Phytochem Anal 2002;13:8-17.

25. Benzie IF, Szeto YT. Total antioxidant capacity of teas by the ferric reducing/antioxidant power assay. J Agric Food Chem 1999;47:633-6.

26. Adedapo AA, Jimoh FO, Koduru S, Masika PJ, Afolayan AJ. Assessment of the medicinal potentials of the methanol extracts of the leaves and 
stems of Buddle jasaligna. BMC Complement Altern Med 2009; 9:21.

27. Sakat S, Tupe P, Juvekar A. Gastroprotective effect of methanol extract of Oxalis corniculata Linn (whole plant) experimental animals. Plant Med 2010;76:P090.

28. Garg VK, Jain ME, Sharma PK, Garg GA. Anti-inflammatory activity of Spinacia oleracea. Int J Pharm Prof Res 2010;1:1-4

29. López-Lázaro M. Distribution and biological activities of the flavonoid luteolin. Mini Rev Med Chem 2009;9:31-59.

30. Zhang LL, Lin YM. Tannins from Canarium album with potent antioxidant activity. J Zhejiang Univ Sci B 2008;9:407-15.

31. Pappa A, Chen C, Koutalos Y, Townsend AJ, Vasiliou V. Aldh3a1 protects human corneal epithelial cells from ultraviolet-and 4-hydroxy2-nonenal-induced oxidative damage. Free Radic Biol Med 2003; 34:1178-89.

32. Li Z, Choi JH, Oh HJ, Park SH, Lee JB, Yoon KC. Effects of eye drops containing a mixture of omega-3 essential fatty acids and hyaluronic acid on the ocular surface in desiccating stress-induced murine dry eye. Curr Eye Res 2014;39:871-8.

33. Cavet ME, Harrington KL, Vollmer TR, Ward KW, Zhang JZ. Antiinflammatory and anti-oxidative effects of the green tea polyphenol epigallocatechin gallate in human corneal epithelial cells. Mol Vis $2011 ; 17: 533$

34. Lee JB, Kim SH, Lee SC, Kim HG, Ahn HG, Li Z, Yoon KC. Blue lightinduced oxidative stress in human corneal epithelial cells: Protective effects of ethanol extracts of various medicinal plant mixtures. Invest Ophthalmol Vis Sci 2014;55:4119-27.

35. Abid RI, Mahmood RI, Rajesh KP, Swamy BE. Potential in vitro antioxidant and protective effect of Cassia fistula Linn. Fruit extracts against induced oxidative damage in human erythrocytes. Int J Pharm Pharm Sci 2014;6:497-505.

36. Reddy NV, Pooja RG, Ganga MR, Sneha JA. Antihyperlipidemic activity of Cassia fistula bark using high-fat diet-induced hyperlipidemia. Int J Pharm Pharm Sci 2015;7:61-4. 